\title{
Long-term trend analysis of climatic variables and reference evapotranspiration over different urban areas in Tunisia
}

\section{Basma Latrech ${ }^{1}, *$ Hiba Ghazouani ${ }^{1,2}$, Lasram Asma ${ }^{1}$, Boutheina M'hamdi Douh $^{1}$, Mansour Mohsen ${ }^{3}$ and Abdelhamid Boujelben ${ }^{1}$}

\author{
${ }^{1}$ Department of Rural Engineering. Higher Institute of Agronomy. Chott_Mariem \\ Sousse (ISA-CM). Université de Sousse. 4042 Tunisia. Email: \\ basma.latrech@gmail.com. \\ ${ }^{2}$ Dipartimento Scienze Agrarie e Forestali. Università degli Studi. Viale delle \\ Scienze 13, 90128. Palermo, Italy. \\ ${ }^{3}$ Regional Research Centre on Horticulture and Organic Agriculture (CRRHAB). \\ Université de Sousse, Tunisia.
}

\begin{abstract}
In this study, the trend analysis of annual climatic variables including $\mathrm{T}_{\max }, \mathrm{T}_{\text {min }}, \mathrm{T}_{\text {mean }}, \mathrm{RH}_{\text {mean, }} \mathrm{WS}$ and $\mathrm{SR}$ as well as FA0-56 PM ET0 were investigated in three locations in Tunisia during 1984-2007. The Mann-Kendall Test, the Sen's Slope Estimator and linear regression tests were used for the analysis. The obtained results showed a significant increasing trends $(\alpha<0.001)$ and $(\alpha<0.01)$ in annual $\mathrm{T}_{\max }, \mathrm{T}_{\min }$ and $\mathrm{T}_{\text {mean }}$ at all the considered locations. However, $\mathrm{T}_{\min }$ increase faster than $\mathrm{T}_{\max }$ with a slope of magnitudes ranging between 0.057 to $0.1^{\circ} \mathrm{C}$ year-1 ${ }^{-1}$. For $\mathrm{RH}_{\text {mean }}$, a non-significant tendency of decrease was observed in Chott-Mariem station. However, significantly increasing trends were found for Kelibia and Tunis Carthage. Concerning the WS variable, a tendency of decrease is observed during the study period for all the stations. Nevertheless, the statistical analysis of decreasing tendency of wind speed varied from non-significant for Tunis Carthage to highly significant ( $\alpha$ $\leq 0.001$ ) at Chott-Mariem and Kelibia. Despite the highly significant upward trend of temperature, the temporal pattern of mean annual FA056 PM-ET0, over the different stations, did not exhibit any significant trend except for Kelibia station.
\end{abstract}

Keywords: Trend analysis; Mann-Kendall Test; Sen's Slope Estimator; Linear regression; Climatic variables; FA056 PM ET0; Tunisia.
Received

December 12, 2018

Accepted

March 29, 2019

Released

April 30, 2019

Full Text Article

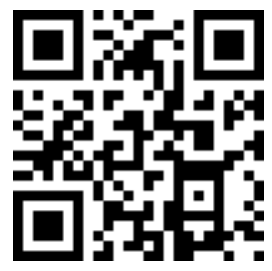

ORCID

(1) 0000-0002-5790-0558 Basma Latrech

(D) 0000-0002-4601-1528

Hiba Ghazouani

(D) 0000-0002-0114-233X

Lasram Asma

(ㄷ) 0000-0002-3439-2212

Boutheina M'hamdi

Douh 


\section{Introduction}

Over the last century, atmospheric concentration of $\mathrm{CO}_{2}$ has increased significantly which resulted in an increment by $0.74{ }^{\circ} \mathrm{C}$ of the average global temperature as compared with the preindustrial era (UNFCCC, 2007). In fact, an increasing trend of urban area has been detected worldwide over the last 50 years which results in a phenomenon called "urban heat islands" where the average temperature within an urban area can be several degrees warmer than the surrounding, undeveloped countryside (Crawley, 2008). In this context, trends in climate change is considered as an indisputable environmental issues (Gocic and Trajkovic, 2014), that have been identified not only in individual parameters, such as temperature or precipitation, but also in integrated parameters, like reference evapotranspiration (ET0) (Ma et al., 2017). Trend analysis of long term time series of climatic variables is a fundamental task in studies on climate change detection that has received a greater attention from scientists (Kumar et al., 2010; Tabari and Hosseinzadeh Talaee, 2011; Asfaw et al., 2018; Kamruzzaman et al., 2018).

Tabari et al. (2011b) studied the trends of the annual maximum, minimum and mean air temperatures and precipitation time series in the west, south and southwest of Iran for the period 1966-2005. They showed warming trend in annual Tmean, Tmax and Tmin at the majority of the stations. However, increasing and decreasing trends of the precipitation series over the region were observed. Kumar et al. (2016), investigated the temporal variation of trend in rainfall, temperature and potential evapotranspiration in the Giridih District in Jharkhand (India) for the period 1901-2002. Their results showed a significant upward trend for maximum and minimum temperature during winter season. Whereas, no significant trend was observed during monsoon and summer seasons. Hence rainfall is concerned, a significant decreasing trend was observed during the monsoon season with a slope value of $2.04 \mathrm{~mm}_{\text {year-1. }}$. Chaouche et al. (2010), analyzed the time series of annually and monthly temperature, rainfall and potential evapotranspiration to assess the climate variability in the western part of the French Mediterranean area. Their results revealed a significant increasing trend of annual mean temperature and potential evapotranspiration, while annual precipitation has not exhibited any trend. They also showed that, at monthly scale, a strong seasonal variability was observed for all the considered climatic variables.

Reference evapotranspiration is, an integrated climate parameter (Ma et al., 2017), widely used for irrigation scheduling, to enhance efficient use of water resources and sustainability of agro-ecosystem productivity as well as to protect the environment (Gocic and Trajkovic, 2014; Minacapilli et al., 2016). Different studies have shown that the FAO-Penman Monteith equation (FA056PM) can be used under different climatic weather. It is considered as the standard method for estimating reference evapotranspiration $\left(\mathrm{ET}_{0}\right)$ since it requires several daily measurements of climatic variables (Minacapilli et al., 2016). Thus, any change in meteorological variables due to climate 
change will affect evapotranspiration (Tabari et al., 2011a). Therefore, several studies have been conducted in order to assess the potential impact of climate change on reference evapotranspiration (Espadafor et al., 2011; Darshana et al., 2013; Pingale et al., 2016). According to climate change model predictions, reference evapotranspiration is presumed to increase in the next years on a par with temperature rise (Espadafor et al., 2011). The results obtained by Tabari et al. (2011a), on investigation of trends in annual, seasonal and monthly reference evapotranspiration in the western half of Iran during 1966-2005, also showed an increasing trend of annual ET0 over 70\% of the stations, when using the nonparametric Mann-Kendall test, with a magnitude of significance varying from +11.28 to +2.30 mm year $^{-1}$. The authors attributed the main cause of increasing in ET0 to the increase in air temperature in the region. In addition, they revealed that, at seasonal scale, the increasing trend was greater in winter and summer than in spring and autumn seasons. Nevertheless, in trend analysis of potential evapotranspiration during 1961-2008 in China, Yin et al. (2010) detected a decreasing trend for the whole country and in most climate regions except for the cold temperate humid region in Northeast China. In addition, $\mathrm{Xu}$ et al. (2006) studied the spatial and temporal patterns of trend in reference evapotranspiration and pan evaporation in Changjiang (Yangtze River) catchment in China, at 150 meteorological stations, for the period 1960-2000. Their results showed a significant decrease in both reference evapotranspiration and pan evaporation for the whole catchment as a consequence of significantly decrease in the net total radiation and wind speed.

Trend analysis of long-term time series consists of the magnitude of trend and its statistical significance (Kumar et al., 2016). Many statistical techniques have been developed to detect trends in meteorological and hydrological time series. They can be classified as parametric and non-parametric tests (Zhang et al., 2006; Gocic and Trajkovic, 2014). Parametric trend tests are more powerful than non-parametric ones, but they require data to be independent and normally distributed (Shadmani et al., 2012). However, non-parametric trend tests are more suitable for non-normally distributed, outlier, censored and missing data, and require only that the data be independent (Asfaw et al., 2018). The Mann-Kendall Test, Sen's Slope Estimator and Spearman's Rho are examples of non-parametric tests that are eventually used to detect the trends in time series (Kumar et al., 2010; Shadmani et al., 2012; Gocic and Trajkovic, 2014; Wang et al., 2014; Pingale et al., 2016; Salami et al., 2016; Djaman et al., 2017; Jaiswal et al., 2018; Kamruzzaman et al., 2018).

A limited number of studies have been carried out on the temporal variability of meteorological data and reference evapotranspiration in Tunisia. Therefore, the objective of this study is to investigate the annual trends of different climatic variables and FAO-56 PM ET0 series over different locations in Tunisia for the period 1984-2007. The temporal variability of the time series were analyzed using the non-parametric Mann-Kendall test and the magnitude of the trend was determined based on the Sen's slope estimator and the linear regression method.

\section{Materials and methods}

\section{Study area and data collection}

Series of daily meteorological data of maximum $\left(\mathrm{T}_{\max }\right)$ and minimum $\left(\mathrm{T}_{\min }\right)$ air temperature, relative humidity $\left(\mathrm{RH}_{\text {mean }}\right)$ and wind speed (WS) were collected from 3 stations over different urban locations in Tunisia for the period 1984-2007. The sunshine duration data are available only for Chott-Mariem station. Due to the lack of this variable in Tunis Carthage and Kelibia stations, data 
relative to solar radiation were taken from POWER-NASA website (http://power.larc.nasa.gov/cgi-

bin/agro.cgi?na). In fact, the suitability of the mentioned website to predict daily

$$
S R=\left(a+b \frac{n}{N}\right) R_{a}
$$

Where: Rs is the solar radiation (MJ m${ }^{-2}$ day $^{-1}$ ), $\mathrm{n}$ is daily bright sunshine duration (h), $\mathrm{N}$ is maximum possible duration of sunshine or daylight hours (h), $\mathrm{n} / \mathrm{N}$ is relative sunshine duration, $\mathrm{Ra}$ is extraterrestrial radiation $\left(\mathrm{MJ} \mathrm{m} \mathrm{m}^{-2}\right.$ day $\left.^{-1}\right), \mathrm{a}$ and $\mathrm{b}$ are regression solar radiation was assessed in semi-arid region in Sicily, Italy, by Negm et al. (2017). However, for Chott-Mariem Station, solar radiation was estimated based on the Angstrom Formula:

coefficients. The recommended values a $=0.25$ and $\mathrm{b}=0.50$ proposed by Allen et al. (1998) were used in this study.

The geographical coordinates of the stations under study are summarized in Table 1.

Table 1. Geographical coordinates and data period of the selected stations

\begin{tabular}{llll}
\hline Locations & Latitude $\left({ }^{\circ} \mathbf{N}\right)$ & Longitude $\left({ }^{\circ} \mathbf{E}\right)$ & Altitude $(\mathbf{m})$ \\
\hline Tunis Carthage & 36.51 & 10.23 & 4 \\
Kelibia & 36.50 & 11.50 & 30 \\
Chott Mariem & 35.50 & 10.34 & 15 \\
\hline
\end{tabular}

\section{Calculation of the reference evapotranspiration (ET0)}

The FAO-56 Penman-Monteith Equation (FAO-56 PM) is recommended by the Food and Agriculture Organization of the United Nations (FAO), as standard equation for estimating ET0 (Allen et al., 1998). The method has been selected because it is physically based and explicitly incorporates both physiological and aerodynamic parameters (Xu et al., 2006):

$$
\mathrm{ET}_{0}=\frac{0.408 \Delta(\mathrm{Rn}-\mathrm{G})+\gamma\left(\frac{900}{\mathrm{~T}_{\operatorname{mean}}+27 \mathrm{~g}}\right) \mathrm{u}_{\mathrm{z}}\left(\mathrm{e}_{\mathrm{g}}-\mathrm{e}_{\mathrm{g}}\right)}{\Delta+\gamma\left(1+0.34 \mathrm{u}_{2}\right)}
$$

Where: ET0 is the reference evapotranspiration $\mathrm{mm} \mathrm{d}^{-1}, \mathrm{Rn}$ the net radiation at the crop surface $\mathrm{MJ} \mathrm{m}^{-2}$ day $^{-1}$, $\mathrm{G}$ the soil heat flux density $\mathrm{MJ} \mathrm{m}^{-2}$ day $^{-1}$, $\mathrm{T}_{\text {mean }}$ the mean daily air temperature at $2 \mathrm{~m}$ height $\left({ }^{\circ} \mathrm{C}\right), \mathrm{u}_{2}$ is the wind speed at $2 \mathrm{~m}$ height $\left(\mathrm{m} \mathrm{s}^{-1}\right), \mathrm{e}_{\mathrm{s}}$ the saturation vapour pressure $(\mathrm{kPa}), \mathrm{e}_{\mathrm{a}}$ the actual vapour pressure $(\mathrm{kPa}), \Delta$ is the slope of vapor pressure curve $\left(\mathrm{kPa}^{\circ} \mathrm{C}^{-1}\right), \quad \gamma$ $\left(\mathrm{kPa}^{\circ} \mathrm{C}^{-1}\right)$ is the air psychrometric constant.
For daily ET0 estimations, G can be neglected, as its magnitude is relatively small.

\section{Temporal trend analysis}

Mann-Kendall Test. The MannKendall test is one of the widely used nonparametric tests to detect significant trends in time series in hydro-climatic variables (Espadafor et al., 2011; Mansour et al., 2017). Two main advantages are attributed to the Mann- 
Kendall Test (Tabari et al., 2011b). First, it does not require the data to be normally distributed. Second, this test is low sensitive to abrupt breaks due to inhomogeneous time series. The related equations for computing the MannKendall test statistic (S) and the standardized test statistic $\mathrm{Z}$ are as follows:

$$
\begin{aligned}
& \mathrm{S}=\sum_{\mathrm{i}=1}^{\mathrm{n}-1} \sum_{\mathrm{j}=\mathrm{i}+1}^{\mathrm{n}} \operatorname{sign}(\mathrm{y}) \\
& \text { Where: } \operatorname{sign}(y)=\operatorname{sign}\left(x_{j}-x_{i}\right)=\left\{\begin{array}{c}
+1 \text { if } \mathrm{y}>0 \\
0 \text { if } \mathrm{y}=0 \\
-1 \text { if } \mathrm{y}<0
\end{array}\right.
\end{aligned}
$$

Where: $x_{j}$ and $x_{i}$ are the annual values in years $j$ and $i(j>i), n$ is the length of the data set. It has been documented that when the number of observations is more than $10(\mathrm{n} \geq 10)$, the statistic $S$ is approximately normally distributed with the mean zero and a variance computed as:

$$
\operatorname{Var}(S)=\frac{n(n-1)(2 n+5)-\sum_{i=1}^{m} t_{i}\left(t_{i}-1\right)\left(2 t_{i}+5\right)}{18}
$$

Where: $\mathrm{n}$ is the number of data points, $\mathrm{m}$ is the number of tied groups (a tied group is a set of sample data having the

$$
Z=\left\{\begin{array}{cc}
\frac{\mathrm{s}-1}{\sqrt{\operatorname{Var}(\mathrm{S})}} & \text { if } \mathrm{S}>0 \\
0 & \text { if } \mathrm{S}=0 \\
\frac{\mathrm{S}+1}{\sqrt{\operatorname{Var}(\mathrm{S})}} & \text { if } \mathrm{S}<0
\end{array}\right.
$$

Where: $\mathrm{Z}$ follows a normal distribution, a very high positive value of $Z$ is an indicator of an increasing trend, and a very low negative value indicates a decreasing trend. When testing a trend at $\alpha$ level of significance, $\mathrm{H}_{0}$ is rejected if the absolute value of $\mathrm{Z}$ is greater than $\mathrm{Z}_{1-\alpha / 2}$.

Sen's Slope Estimator. The nonparametric Sen's slope estimator, following the Mann-Kendall test, was employed to determine the magnitude of the slope of the trend in the time series (change per year of the trends) inthe hydro-climatic time series. Details of the same value), and $t_{i}$ is the number of data points in the $\mathrm{i}^{\text {th }}$ group. The standardized test statistic $\mathrm{Z}$ is computed as follow: method are available in (Tabari and Hosseinzadeh Talaee, 2011).

The Mann Kendall test and Sen's slope estimator calculations for various time series of climate variables and ET0 were performed using the Excel-based template MAKESENS 1.0, developed by researchers at the Finnish Meteorological Institute (Salmi et al., 2002).

Linear regression method. Simple linear regression as well as MannKendall Test and Sen's Slope Estimator, is applied for identifying linear trend in a time series. The main statistical 
parameter obtained from the regression analysis is, the slope, indicates the mean temporal change of the studied variable. Positive values of the slope show increasing trend, while negative values of the slope indicate decreasing trend. The total change during the period under observation is obtained by multiplying the slope by the number of years (Tabari and Hosseinzadeh Talaee, 2011).

\section{Results and discussion}

\section{Temperature trends}

The main results of the nonparametric Mann-Kendall test, the Sen's slope estimator and linear regression applied to detect the annual trends in minimum, maximum, and mean air temperature over the considered locations for the period (1984-2007) are summarized in Table 2.

A clear warming trend for $\mathrm{T}_{\text {mean, }}$, $\mathrm{T}_{\max }$, and $\mathrm{T}_{\min }$ annual values was detected for all the investigated stations. For Tmean, a high significant increasing trend was found $(\alpha \leq 0.001)$ for all the stations. The magnitude of the significant increasing trend ranged between $0.05^{\circ} \mathrm{C}_{\text {year }}-1$ and $0.072^{\circ} \mathrm{C}_{\text {year }}{ }^{-1}$, respectively for Chott Mariem and Kelibia station. In fact, the Sen's slope values of annual $\mathrm{T}_{\text {mean }}$ are of the same order of magnitude of that referred by (Wang et al., 2014) who found a slope value of annual trend in $\mathrm{T}_{\text {mean }}$ equal to $0.06^{\circ} \mathrm{C}$ year-1 in Hetao station (Northern China) for the period 1954-2012. These results are also in good agreement with those published by (Tabari et al., 2011a; Kamruzzaman et al., 2018), who found a significant upward trend in annual Tmean in $70 \%$ of the stations located in the western half of Iran and in different stations in the western part of Bangladesh respectively using the MannKendall test.

Table 2. Statistical tests for annual minimum, maximum, and mean air temperature over the period 1984-2007.

\begin{tabular}{lcccccc}
\hline Locations & First year & Last year & Test Z & Signific. & Sen's slope & b $\left({ }^{\circ} \mathbf{C} / \mathbf{y e a r}\right)$ \\
\hline $\mathbf{T}_{\mathbf{m a x}}$ & & & & & & \\
Kelibia & 1984 & 2007 & 3.696 & $* * *$ & 0.064 & 0.062 \\
Tunis Carthage & 1984 & 2007 & 2.803 & $* *$ & 0.056 & 0.050 \\
Chott Mariem & 1984 & 2007 & 2.928 & $* *$ & 0.045 & 0.044 \\
$\mathbf{T}_{\text {min }}$ & & & & & & \\
Kelibia & 1984 & 2007 & 3.894 & $* * *$ & 0.059 & 0.057 \\
Tunis Carthage & 1984 & 2007 & 4.390 & $* * *$ & 0.106 & 0.111 \\
Chott Mariem & 1984 & 2007 & 3.101 & $* *$ & 0.057 & 0.056 \\
$\mathbf{T}_{\text {mean }}$ & & & & & & 0.059 \\
Kelibia & 1984 & 2007 & 3.944 & $* * *$ & 0.062 & 0.081 \\
Tunis Carthage & 1984 & 2007 & 3.944 & $* * *$ & 0.082 & 0.050 \\
Chott Mariem & 1984 & 2007 & 3.349 & $* * *$ & 0.050 & \\
\hline
\end{tabular}

*** $\alpha=0.001$ level of significance; ${ }^{* *} \alpha=0.01$ level of significance.

For both Tmin and Tmax variables, the increase was statistically significant, with a significant level of at $\alpha \leq 0.001$ and $\alpha \leq 0.01$. The magnitudes of the significant increasing trends varies between 0.045 and $0.064^{\circ} \mathrm{C}$ year- ${ }^{-1}$ and from 0.57 to $0.1^{\circ} \mathrm{C}$ year -1 for $\mathrm{T}_{\max }$ and $\mathrm{T}_{\min }$, respectively. These values are of the same magnitude with those obtained with the linear regression method. A more detailed analysis evidenced that the increment of the minimum 
temperature is faster than the maximum. Similar results were obtained by Asfaw et al. (2018), Karl et al. (1993), and Wang et al. (2014), who found that the increasing trends in the $\mathrm{T}_{\min }$ series were more pronounced than those in the $\mathrm{T}_{\max }$ series. According to Soltani and Soltani (2008) and Tabari and Hosseinzadeh Talaee (2011), the warming trends in $\mathrm{T}_{\min }$ and $\mathrm{T}_{\max }$, may refer to global warming and other probable reasons such as increased concentrations of anthropogenic greenhouse gases, increased urbanization and industrialization, aerosols which exert cooling effects on the climate increase in natural and anthropogenic clouds.

\section{Relative humidity trends}

The Mann-Kendall Test, Sen's Slope Estimator and linear regression were also applied to detect annual trends in $\mathrm{RH}$ for the stations under study during the period 1984-2007. The obtained results are summarized in Table 3.

Table 3. Statistical tests for annual Relative Humidity over the period 1984-2007.

\begin{tabular}{lcccccc}
\hline Locations & First year & Last year & Test Z & Signific. & Sen's slope & b (\%/year) \\
\hline Kelibia & 1984 & 2007 & 2.307 & $*$ & 0.251 & 0.329 \\
Tunis Carthage & 1984 & 2007 & 1.811 & + & 0.311 & 0.359 \\
Chott Mariem & 1984 & 2007 & -0.372 & ns & -0.025 & 0.025 \\
\hline
\end{tabular}

ns: non-significant; ${ }^{*} \alpha=0.05$ level of significance; $+\alpha=0.1$ level of significance.

A mix of positive and negative trends was identified when using the Mann-Kendall Test. A significantly increasing trends $(\alpha \leq 0.05)$ and $(\alpha \leq 0.1)$ were observed for Kelibia and Tunis Carthage stations, while a non-significant trend was detected at Chott Mariem station. The magnitude of the significant increasing trends is around 0.25 and $0.31 \%$ year $^{-1}$ respectively for Kelibia and $^{-}$ Tunis Carthage. Salami et al. (2016), observed a significant positive trend in annual relative humidity, using MannKendall test, at Victoria Island Marine Station for the period 1992-2012. Nevertheless, these results are in disagreement with the findings of Djaman et al. (2017), Espadafor et al. (2011) and Ma et al. (2017), who found a significant decreasing trends in annual relative humidity when using Mann-
Kendall Test, whereas, they revealed a positive trends at a specific seasonal scales. On the other hand, in the western half of Iran, the percentage of stations with a significant increasing trends in annual relative humidity are equal to the significant decreasing ones (Tabari et al., 2011a). However, for seasonal scale, the number of stations with significant positive trends is greater than those with significant negative trends except for winter season.

\section{Wind speed trends}

Mean values of wind speed have been analyzed for all stations under study using Mann-Kendall Test, Sen's Slope Estimator and linear regression. The obtained results are summarized in Table 4. 
Table 4. Statistical tests for annual wind speed over the period 1984-2007.

\begin{tabular}{lcccccc}
\hline Locations & First year & Last year & Test Z & Signific. & Sen's slope & b (m/s/year) \\
\hline Kelibia & 1984 & 2007 & -4.539 & $* * *$ & -0.051 & -0.049 \\
Tunis Carthage & 1984 & 2007 & -0.571 & ns & -0.012 & -0.013 \\
Chott Mariem & 1984 & 2007 & -4.093 & $* * *$ & -0.019 & -0.018 \\
\hline
\end{tabular}

ns: non-significant; ${ }^{* * *} \alpha=0.001$ level of significance

Among the study stations, Tunis Carthage did not exhibited any significant trend in term of annual wind speed. However, significant negative trends were detected for Kelibia and Chott-Mariem stations at $\alpha \leq 0.001$ significance level. The magnitude of decrease in annual wind speed were around $(-0.5)$ and $(-0.2) \mathrm{m} \mathrm{s}^{-1}$ decade $^{-1}$ for Kelibia and Chott-Mariem, respectively. The same magnitude of slope is achieved when using both Mann Kendall and linear regression methods. The negative trend of annual wind speed might be as a result of the rapid urbanization pressure increase in recent years. In fact, Weber and Puissant (2003), have located and quantified an increase of built-up areas of $13 \%$ in 10 years (1986_1996) in the periphery of the Metropolitan Area of Tunis. Considering Chott Mariem station, the achieved results are consistent with those recently published by Mansour et al. (2017) in investigation carried out at the same station for the period 19732007. The authors, revealed a significantly decreasing trend $(\alpha \leq 0.001)$ in annual wind speed using MannKendall Test. In addition, relatively similar results were obtained by Ma et al. (2017), who found a significantly decreasing trend in annual and seasonal wind speed, using Mann-Kendall Test, in investigation in 21 stations around the Songnen Grassland, Northeast China, during 1960-2014. Furthermore, Yin et al. (2010), observed a significantly decreasing trend in wind speed in most climate regions in China mainly distributed in West and North China, during the study period.

\section{Solar radiation trends}

The results of the application of the Mann-Kendall Test, Sen's Slope Estimator and linear regression tests for trend identification of annual solar radiation are summarized in Table 5.

Table 5. Statistical tests for annual solar radiation over the period 1984-2007,

\begin{tabular}{lcccccc}
\hline Locations & First year & Last year & Test Z & Signific. & Sen's slope & b $\left(\mathbf{M J m}^{-2} \mathbf{d a y}^{-\mathbf{1}} \mathbf{y e a r}^{-\mathbf{1}} \mathbf{)}\right.$ \\
\hline Kelibia & 1984 & 2007 & 2.654 & $* *$ & 0.045 & 0.068 \\
Tunis Carthage & 1984 & 2007 & 1.315 & ns & 0.027 & 0.024 \\
Chott Mariem & 1984 & 2007 & 1.737 & + & 0.032 & 0.032 \\
\hline
\end{tabular}

ns: non-significant; $+\alpha=0.1$ level of significance; ** $\alpha=0.01$ level of significance.

In general, positive trends were detected for all the considered stations. A significant upward trend was observed for Kelibia and Chott-Mariem stations with a significance level of $(\alpha \leq 0.01)$ and $(\alpha \leq 0.1)$, respectively, while, no significant positive trend was observer for Tunis Carthage station. The Sen's slope values are about 0.45 and $0.32 \mathrm{MJm}^{-2}$ day $^{-1}$ decade $^{-1}$, respectively for Kelibia and Chott-Mariem. Previous works also detected a clear linear increasing tendency of solar radiation as from 1980s, after a decrease during 1950-1980 (Wild, 2009; Espadafor et al., 2011) Moreover, for Chott-Mariem, the 
test $\mathrm{Z}$ value (1.74) is of the same magnitude of that inferred by Mansour et al. (2017), while a negligible difference was noticed between the two values related to the difference between the considered study periods.

\section{Reference evapotranspiration trends}
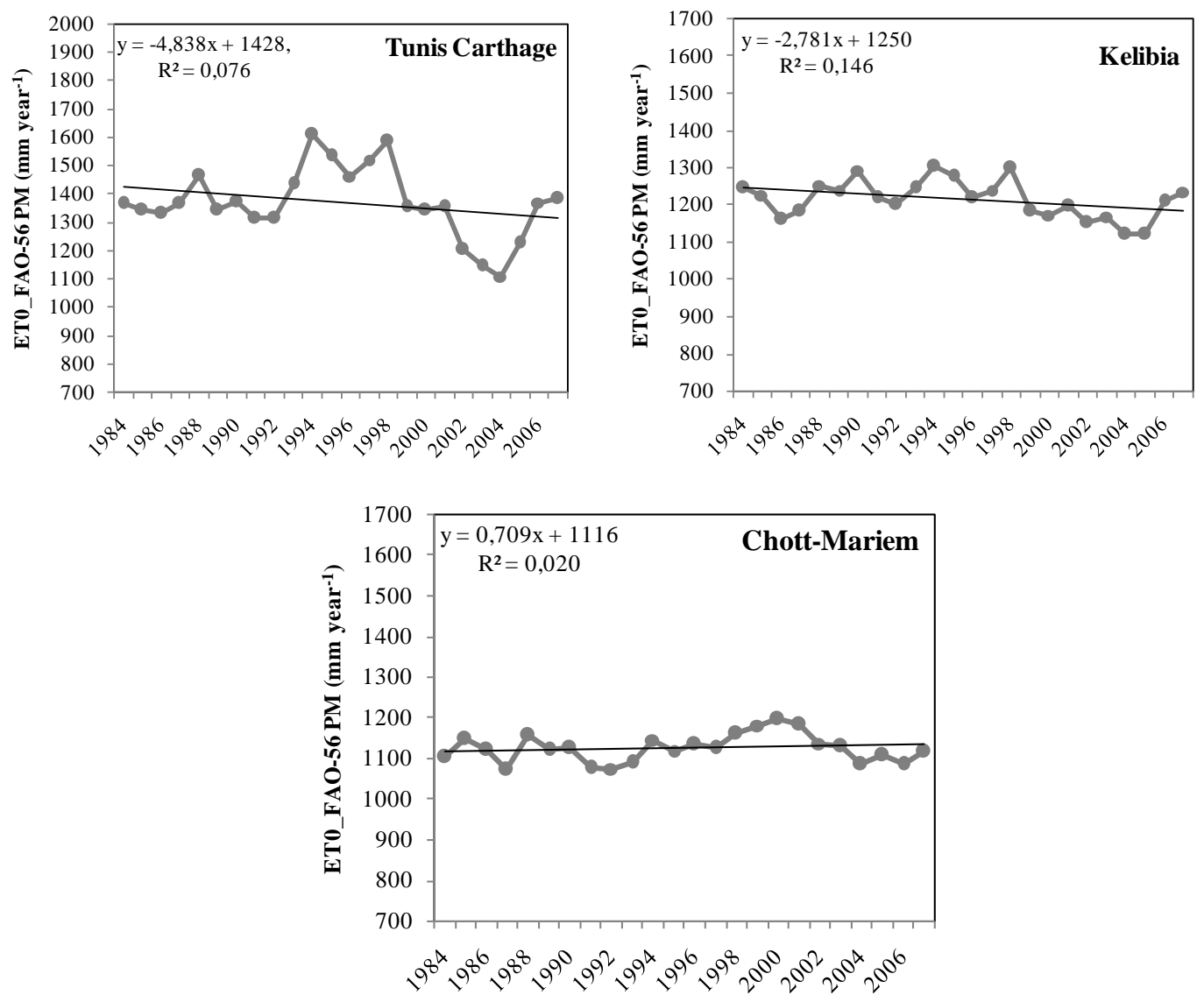

Figure 1. Time series and linear trends of annual FAO-56 PM ET0 at all the considered stations.

Table 6. Statistical tests for annual reference evapotranspiration over the period 1984-2007.

\begin{tabular}{lcccccc}
\hline Locations & First year & Last year & Test Z & Signific. & Sen's slope & b (mm/year) \\
\hline Kelibia & 1984 & 2007 & -1.811 & + & -3.121 & -2.781 \\
Tunis Carthage & 1984 & 2007 & -0.769 & ns & -3.182 & -4.838 \\
Chott Mariem & 1984 & 2007 & 0.620 & ns & 0.683 & 0.709 \\
\hline
\end{tabular}

ns: non-significant; $+\alpha=0.1$ level of significance. 
The Mann-Kendall Test showed a significantly decreasing trend $(\alpha<0.1)$ for Kelibia Station with a slope of magnitude of -3.12 mm year $^{-1}$. Despite the increasing trend in annual temperature among all the investigated stations, no significant positive or negative trend was detected by the nonparametric Mann-Kendall Test in annual ET0 for Tunis Carthage and ChottMariem Stations. These results are consistent with those obtained by Gocic and Trajkovic (2014) and De La Casa and Ovando (2016) who investigated trend analysis of reference evapotranspiration, over 21 stations in Serbia and in the Central Region of Argentina, respectively. The authors found that, according to Mann-Kendall Test, $41.67 \%$ among all the studied stations in Serbia, and more than $91 \%$ of the central region of Argentina didn't exhibited any significant annual trends in term of ET0. On the other hand, ET0 has been shown to increase in different locations throughout the world (Chaouche et al., 2010; Espadafor et al., 2011; Tabari et al., 2011a). In contrast to the expected upward trend in reference evapotranspiration as a consequence of temperature rise, significant decreasing trend in reference evapotranspiration were detected in different regions (Roderick et al., 2004; Chen et al., 2005; Xu et al., 2006; Yin et al., 2010; Darshana et al., 2013).

According to Irmak et al. (2012), there is no scientific common findings about which meteorological variable(s) mainly responsible on the general decrease in ET0 and that the trend and magnitude of reference evapotranspiration cannot be influenced by only one or two climatic variables. Thus, they all need be collectively accounted for in a combination-based energy balance equations when used in climate change study. Xu et al. (2006), showed that the decrease in ET0 is due to the decreasing trend is the net total radiation followed by wind speed. Chattopadhyay and
Hulme (1997), in investigation over the Indian region, indicated that both pan evaporation (Epan) and ET0 have decreased and that increases in relative humidity and decreases in radiation were correlated with the decreasing trend in ET0. In addition, Irmak et al. (2012), suggest that decrease in ET0 is mainly due to significant increase in precipitation that results in significant reduction in Rs and Rn. Furthermore, the authors revealed that decreasing trend in wind speed would generate a decreasing trend in ET0 under the assumption that the other meteorological variables that drive ET0 remain constant.

\section{Conclusion}

Trend analysis of climatic variables and reference evapotranspiration were analyzed using the MannKendall test, the Sen's slope estimator and linear regression method for three climatic stations in Tunisia during 19842007. At an annual time scale, the trend tests showed a statistically significant increase in Tmean, Tmax and Tmin in all the analyzed locations. In addition, significantly decreasing trends of wind speed series were observed for Kelibia and Chott-Mariem stations as a result of the rapid urbanization. Moreover, significant increasing trends were detected in term of solar radiations for both Kelibia and Chott-Mariem stations. The results also revealed that, except for Kelibia, there were no significant upward or downward trends in the annual FAO56 PM ET0.

The observed behavior of ET0 trend could be justified by the antagonist effect between the aerodynamic and energetic components of evapotranspiration term. Thus, it can be inferred from the results that the trend and magnitude of reference evapotranspiration cannot be defined by the effect of single climatic variables and that it resulted from the combined effect of each parameter. 
The results of the study, suggest the need for more detailed analysis on the effect of climate change on climatic variables and reference evapotranspiration at different time scales and to investigate the sensitivity of reference evapotranspiration to each climatic variables in time and space. Finally, for agricultural purposes, these results are to be considered only for urban agriculture since the stations under study are placed in urban areas.

\section{Conflict of interest}

The authors declare that there are no conflicts of interest.

\section{References}

Allen, R.; Pereira, S.; Raes, D.; Smith, M. Crop evapotranspiration guidelines for computing crop water requirements. Rome: FAO, 1998. (Irrigation and Drainage, 56).

Asfaw, A.; Simane, B.; Hassen, A.; Bantider, A. Variability and time series trend analysis of rainfall and temperature in northcentral Ethiopia: A case study in Woleka Sub-Basin. Weather and Climate Extremes, v. 19, p. 29-41, 2018. https://doi.org/10.1016/ j.wace.2017.12.002

Chaouche, K.; Neppel, L.; Dieulin, C.; Pujol, N.; Ladouche, B.; Martin, E.; Salas, D.; Caballero, Y. Analyses of precipitation, temperature and evapotranspiration in a French Mediterranean region in the context of climate change. ComptesRendus Geoscience, v. 34, p. 234-243, 2010. https://doi.org/10.1016/j.crte.2010.02.001

Chattopadhyay, N.; Hulme, M. Evaporation and potential evapotranspiration in India under conditions of recent and future climate change. Agricultural and Forest Meteorology, v. 87, p. 55-73, 1997. https://doi.org/10.1016/S0168-1923(97) 00006-3

Chen, D. L.; Gao, G.; Xu, C. Y.; Guo, J.; Ren, G. Y. Comparison of the Thornthwaite Method and pan data with the standard Penman-Monteith estimates of reference evapotranspiration in China. Climate Research, v. 28, p. 123-132, 2005. https://doi.org/10.3354/cr028123
Crawley, D. B. Estimating the impacts of climate change and urbanization on building performance. Journal of Building Performance Simulation, v. 1, no. 2, p. 91115, 2008. https://doi.org/10.1080/ 19401490802182079

Darshana; Pandey, A.; Pandey, R. P. Analysing trends in reference evapotranspiration and weather variables in the Tons River Basin in Central India. Stochastic Environmental Research and Risk Assessment, v. 7, no. 6, p. 1407-1421, $2013 . \quad$ https://doi.org/ 10.1007/s00477-012-0677-7

De La Casa, A. C.; Ovando, G. G. Variation of reference evapotranspiration in the central region of Argentina between 1941 and 2010. Journal of Hydrology: Regional Studies, v. 5, p. 66-79, 2016. https://doi.org/ 10.1016/j.ejrh.2015.11.009

Djaman, K.; Balde, A. B.; Rudnick, D. R.; Nadiaye, O.; Irmak, S. Long-term trend analysis in climate variables and agricultural adaptation strategies to climate change in the Senegal River Basin. International Journal of Climatology, v. 37, no. 6, p. 2873-2888, 2017. https://doi.org/10.1002/joc.4885

Espadafor, M.; Lorite, I. J.; Gavilán, P.; Berengena, J. An analysis of the tendency of reference evapotranspiration estimates and other climate variables during the last 45 years in Southern Spain. Agricultural Water Management, v. 98, no. 6, p. 1045-1061, 2011. https://doi.org/10.1016/j.agwat. 2011.01.015

Gocic, M.; Trajkovic, S. Analysis of trends in reference evapotranspiration data in a humid climate. Hydrological Sciences Journal,

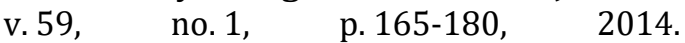
https://doi.org/10.1080/02626667.2013.79 8659

Irmak, S.; Kabenge, I.; Skaggs, K.E.; Mutiibwa, $D$. Trend and magnitude of changes in climate variables and reference evapotranspiration over 116-yr period in the Platte River Basin, central Nebraska-USA. Journal of Hydrology, v. 420-421, p. 228-244, 2012. https://doi.org/10.1016/j.jhydrol.2011.12.0 06

Jaiswal, A.; Samuel, C.; Kadabgaon, V. M. Statistical trend analysis and forecast modeling of air pollutants. Global Journal of Environmental Science and Management, 
v. 4 , no. 4, p. 427-438, 2018. https://doi.org/ 10.22034/gjesm.2018.04.004

Kamruzzaman, M.; Rahman, A. T. M. S.; Ahmed, M. S.; Kabir, M. E.; Mazumder, Q. H.; Rahman, M. S.; Jahan, C. S. Spatio-temporal analysis of climatic variables in the western part of Bangladesh. Environment, Development and Sustainability, v. 20, no. 1, p. 89-108, 2018. https://doi.org/ 10.1007/s10668-016-9872-x

Karl, T. R.; Jones, P. D.; Knight, R. W.; Kukla, G.; Plummer, N.; Razuvayev, V.; Gallo, K. P.; Lindseay, J.; Charlson, R. J.; Peterson, T. C. A new perspective on recent global warming_Asymmetric trends of daily maximum and minimum temperature. Bulletin of the American Meteorological Society, v. 74, no. 6, p. 1007-1023, 1993. https://doi.org/10.1175/1520-0477(1993) 074<1007:ANPORG>2.0.CO;2

Kumar, V.; Jain, S. K.; Singh, Y. Analysis of long-term rainfall trends in India. Hydrological Sciences Journal, v. 55, no. 4, p. 484-496, 2010. https://doi.org/10.1080/ 02626667.2010 .481373

Kumar, M.; Denis, D. M.; Shakti, S. Long-term climatic trend analysis of Giridih District, Jharkhand (India) using statistical approach. Modeling Earth Systems and Environment, 2:116, 2016. https://doi.org/10.1007/ s40808-016-0162-2

Ma, Q.; Zhang. J.; Sun, C.; Guo, E.; Zhang, F., Wang, M. Changes of reference evapotranspiration and its relationship to dry/wet conditions based on the Aridity Index in the Songnen Grassland, Northeast China. Water, v. 316, no. 9, 316, 2017. https://doi.org/10.3390/w9050316

Mansour, M.; Hachicha, M.; Mougou, A. Trend analysis of potential evapotranspiration case of Chott-Meriem Region (The Sahel of Tunisia). International Journal of Agriculture Innovations and Research, v. 5, no. 5, p. 703-708, 2017. https://doi.org/ 10.1016/j.agwat.2015.12.004

Minacapilli, M.; Cammalleri, C.; Ciraolo, G.; Rallo, G.; Provenzano, G. Using scintillometry to assess reference evapotranspiration methods and their impact on the water balance of olive groves. Agricultural Water Management, v. 170, p. 49-60, 2016. https://doi.org/10.1016/j.agwat.2015.12.004
Negma, A.; Jabro, J.; Provenzano, G. Agricultural and forest meteorology assessing the suitability of American National Aeronautics and Space Administration (NASA) agro-climatology archive to predict daily meteorological variables and reference evapotranspiration in Sicily, Italy. Agricultural and Forest Meteorology, v. 244-245, p.111-121, 2017. https://doi.org/10.1016/j.agrformet.2017.05 .022

Pingale, S. M.; Khare, D.; Jat, M. K.; Adamowski, J. Trend analysis of climatic variables in an arid and semi-arid region of the Ajmer District, Rajasthan, India. Journal of Water and Land Development, v. 28, p. 3-18, 2016. https://doi.org/10.1515/jwld2016-0001

Roderick, M. L.; Farquhar, G. D. Changes in Australian pan evaporation from 1970 to 2002. International Journal of Climatology, v. 24, no. 9, p. 1077-1090, 2004. https://doi.org/10.1002/joc.1061

Salami, A. W.; Ikpee, O. D.; Ibitoye, A. B.; Oritola, S. F. Trend analysis of hydrometeorological variables in the coastal area of Lagos using Mann-Kendall trend and Standard Anomaly Index Methods. Journal of Applied Sciences and Environmental Management, v. 20, no. 3, p. 797-808, 2016. https://doi.org/10.4314/jasem.v20i3.34

Salmi, T.; Maatta, A.; Anttila, P.; Ruoho-Airola, T.; Amnell, T. Detecting trends of annual values of atmospheric pollutants by the Mann-Kendall Test and Sen's Slope Estimates: The excel template application MAKESENS. Yogyakarta, The Republic of Indonesia: Universitas Gadjah Mada, 2002. (Report Code FMIAQ-31,).

Shadmani, M.; Marofi, S.; Roknian, M. Trend analysis in reference evapotranspiration using Mann-Kendall and Spearman's Rho Tests in arid regions of Iran. Water Resource Management, v. 26, no. 1, p. 211224, 2012. https://doi.org/10.1007/s11269011-9913-z

Soltani, E.; Soltani, A. Climatic change of Khorasan, North-East of Iran, during 19502004. Research Journal of Environmental Sciences, v. 2, no. 5, p. 316-322, 2008. https://doi.org/10.3923/rjes.2008.316.322 
Tabari, H.; Hosseinzadeh Talaee, P. Analysis of trends in temperature data in arid and semi-arid regions of Iran. Global and Planetary Change, v. 79 , no. $1 / 2$, p. $1-10$, 2011. https://doi.org/10.1016/j.gloplacha. 2011.07.008

Tabari, H.; Marofi, S.; Aeini, A.; HosseinzadehTalaee, P.; Mohammadi, K. Trend analysis of reference evapotranspiration in the western half of Iran. Agricultural and Forest Meteorology, v. 151 , no. 2 , p. $128-136, \quad 2011 \mathrm{a}$. https://doi.org/10.1016/j.agrformet.2010.09 .009

Tabari, H.; ShiftehSomee, B.; Rezaeian Zadeh, M. Testing for long-term trends in climatic variables in Iran. Atmospheric Research, v. 100 , no. $1, \quad$ p. $132-140, \quad 2011$ b. https://doi.org/10.1016/j.atmosres.2011.01. 005

UNFCCC - United Nations Framework Convention on Climate Change. Climate change: Impacts, vulnerabilities and adaptation in developing countries. Bonn, Germany: UNFCCC, 2007.

Wang, X.-M.; Liu, H.-J.; Zhang, L.-W.; Zhang, R.$\mathrm{H}$. Climate change trend and its effects on reference evapotranspiration at Linhe Station, Hetao Irrigation District. Water Science and Engineering, v. 7, no. 3, p. 250266, 2014. https://doi.org/10.3882/ j.issn.1674-2370.2014.03.002
Weber, C.; Puissant, A. Urbanization pressure and modeling of urban growth: Example of the Tunis Metropolitan Area. Remote Sensing of Environment, v. 86, no. 3 p. 341352, 2003. https://doi.org/10.1016/S00344257(03)00077-4

Wild, M. Global dimming and brightening: A review. JGR Atmosphere, v. 114, no. D10, 2009. 2008JD011470 https://doi.org/10.1029/

Xu, C.-Y.; Gong, L.; Jiang, T.; Chen, D.; Singh, V.P. Analysis of spatial distribution and temporal trend of reference evapotranspiration and pan evaporation in Changjiang (Yangtze River) catchment. Journal of Hydrology, v. 327, no. 1/2, p. 81-93, 2006. https://doi.org/10.1016/j.jhydrol.2005.11.0 29

Yin, Y.; Wu, Sh.; Chen, G.; Dai, E. Attribution analyses of potential evapotranspiration changes in China since the 1960s. Theoretical and Applied Climatology, v. $101, \quad$ no. $1 / 2, \quad$ p. $19-28, \quad 2010$. https://doi.org/10.1007/s00704-009-0197-7

Zhang, Q.; Liu, C.; Xu, C.-Y.; Xu, Y.; Jiang, T. Observed trends of annual maximum water level and streamflow during past 130 years in the Yangtze River Basin. China. Journal of Hydrology, v. 324, no. 1/4, p. 255-265, 2006. https://doi.org/10.1016/j.jhydrol.2005.09.0 23 